Vol. 7. No.2, Agustus, 2018: 83-106, ISSN (cet): 2355-1755 | ISSN (online): 2579-6437

\title{
PENERAPAN MANAJEMEN MUTU DALAM MENINGKATKAN KINERJA KEUANGAN BNI SYARIAH PERIODE 2010 - 2017
}

\author{
Galuh Gita Pratiwi' ${ }^{1}$, Nur S.Buchori ${ }^{2}$, Mustafa Kamal ${ }^{3}$
}

\author{
${ }^{1}$ Operator TK Yayasan Himmatul Ulum Al Islami. Email : galuhgitapratiwi234@gmail.com \\ ${ }^{2}$ Prodi Perbankan Syariah, Sekolah Tinggi Ekonomi Islam SEBI, Depok, Jawa Barat. Email: \\ buchori6632@gmail.com, \\ ${ }^{32}$ Prodi Akuntansi Syariah, Sekolah Tinggi Ekonomi Islam SEBI, Depok, Jawa Barat. Email: \\ mustafast@yahoo.com
}

\begin{abstract}
ABSTRAK. Penelitian ini bertujuan untuk mengetahui dampak penerapan manajemen mutu dalam meningkatkan kinerja keuangan BNI Syariah. Metode yang digunakan untuk mengukur kinerja keuangan pada penelitian ini adalah dengan membandingkan rasio-rasio keuangan (rasio kecukupan modal, rasio rentabilitas, dan rasio likuiditas) BNI Syariah. Adapun metode pengumpulan data yang digunakan adalah wawancara dan laporan tahunan BNI Syariah Tahun 2010 sampai 2017. Hasil penelitian ini adalah manajemen mutu yang diterapkan BNI Syariah memiliki dampak positif pada rasio kecukupan modal serta rasio rentabilitas khususnya ROA dan ROE. Adapun penerapan manajemen mutu yang diterapkan BNI Syariah sesuai dengan prinsip Total Quality Management yang dicanangkan oleh ISO, yaitu fokus pada pelanggan, kepemimpinan, keterlibatan semua pihak, pendekatan proses, perbaikan berkelanjutan, pengambilan keputusan berdasarkan bukti serta pengelolaan hubungan.
\end{abstract}

Kata Kunci : Manajemen Mutu, Kinerja Keuangan, Rasio Keuangan, BNI Syariah

\begin{abstract}
The aims of this reasearch is to know the impact implimentation of quality management to increase BNI Syariah financial performance. The methods used to measure financial performance in this study is to compare BNI Syariah financial ratios (capital adequacy ratio, rentability ratio, and liquidity ratio). As for the collection methode in this research is used interview and BNI Syariah annual report periode 2010 untill 2017. The result of this study is quality management applied to BNI Syariah has positive impact on the capital adequacy ratio and profability, especially ROA and ROE. As for the implementation of the management quality applied BNI Syariah in accordance with the principles TQM that proclaimed by ISO, namely the customer focus, leadership, enggagement of people, processing approach, improvement, evidence based decision making, and relationship management.
\end{abstract}

Keyword : Quality Management, Financial Performance, Financial Ratio 


\section{PENDAHULUAN}

Globalisasi merupakan istilah untuk menggambarkan masuknya dunia internasional pada aspek-aspek kehidupan yang ada disuatu Negara. Adanya globalisasi ini menyebabkan tingkat persaingan yang ada di dalam Negeri semakin meningkat, termasuk di Indonesia sendiri (Muhammad, 2015, hal. 1). Salah satu contoh globalisasi yang di alami oleh Indonesia sendiri adalah dengan adanya MEA (Masyarakat Ekonomi ASEAN). Adanya MEA ini membuat tingkat pesaingan ekonomi di tanah air semakin meningkat, sehingga menyebabkan pasar-pasar lokal yang ada di Indonesia harus terus melakukan inovasi secara terus menerus untuk mempertahankan eksistensinya, begitupun dengan lembaga keuangan yang ada di Indonesia, termasuk perbankan, baik perbankan konvensional maupun perbankan syariah. (Azwar, 2015).

Perbankan merupakan lembaga intermediary yang berperan dalam menjaga kestabilan sistem keuangan bangsa. Indonesia memiliki dua sistem perbankan yang beroperasi atau yang lebih dikenal dengan dual banking system, yaitu perbankan konvensional dan perbankan syariah. Kedua lembaga tersebut memiliki kesamaan dalam menjalankan perannya sebagai lembaga intermediary dan untuk menjaga stabilitas Negara. Akan tetapi, terdapat perbedaan mendasar antara bank syariah dengan bank konvensional, perbedaan tersebut terletak pada prinsip yang digunakan dalam menjalankan kegiatannya. Perkembangan sistem perbankan syariah di Indonesia yang dimulai sejak tahun 1980, sudah banyak pencapaian kemajuan, baik dari aspek lembagaan dan infrastruktur penunjang, perangkat regulasi dan sistem pengawasan, maupun awareness dan literasi masyarakat terhadap layanan jasa keuangan syariah. Sistem keuangan syariah kita menjadi salah satu sistem terbaik dan terlengkap yang diakui secara internasional (Otoritas Jasa Keuangan).

Otoritas Jasa Keuangan (OJK) mencatat perkembangan total aset yang diperoleh BUS\&UUS periode 2015 hingga 2017. Pada periode 2015 total aset yang dimiliki BUS dan UUS mencapai angka Rp 213.243 miliyar, hal ini menunjukkan adanya peningkatan total aset sebesar 40,19\% dari periode sebelumnya, yaitu periode 2016 dengan total aset sebesar Rp 356.504 miliyar. Adapun pada periode 2017, telah tercatat total aset yang dimiliki BUS dan UUS mencapai Rp 424.181 atau tumbuh sebesar 15,96\% dari periode 2016.

Adanya peningkatan jumlah aset BUS dan UUS tersebut, menandakan bahwa terdapat peningkatan kinerja yang dilakukan oleh BUS dan UUS. Hal ini juga menujukkan bahwa perbankan syariah, baik BUS maupun UUS mampu bersaing di tengah persaingan yang semakin ketat. Kendati demikian, perbankan syariah harus selalu melakukan inovasi maupun perbaikan secara terus menerus untuk menghasilkan mutu (kualitas) produk maupun pelayanan yang baik. Dalam hal ini, mutu adalah satu hal penting yang harus diperhatikan oleh setiap entitas. Kualitas mutu yang baik pada suatu barang maupun pelayanan (jasa) akan memengaruhi minat suatu pelanggan/ nasabah. Semakin baik mutu barang atau pelayanan (jasa) yang diberikan, maka kepuasan pelanggan atau nasabah akan tercipta. 
Jurnal Ekonomi dan Perbankan Syariah

Vol. 7. No.2, Agustus 2018: 83-106, ISSN (cet): 2355-1755 | ISSN (online): 25796437

\section{| 85}

Philip Kotler (1994) menyatakan bahwa, "Quality is our best assurance of customer allegiance, our strongest defence against foreign competition and the only path to sustain growth and earnings" (Natha, 2008, hal. 4). Berdasarkan pemaparan diatas, penulis menyetujui gagasan yang dipaparkan oleh Philip Kotler yang menyatakan bahwa kualitas/ mutu adalah kepastian dari kesetiaan customer dan kekuatan dalam bertahan ditengah kompetisi yang selektif serta jalan untuk menopang pertumbuhan dan nilai perusahaan.

Mullins (1999, halaman 37) menyatakan bahwa Total Quality Management (TQM) atau lebih dikenal dengan istilah manajemen mutu, sebuah cara hidup untuk organisasi secara keseluruhan, berkomitmen untuk kepuasan pelanggan melalui proses terus-menerus perbaikan dan kontribusi dan keterlibatan (Haque \& dkk, 2014, hal. 7). Total Quality Management (TQM) bukan merupakan tujuan akhir perusahaan atau organisasi, melainkan suatu cara untuk mencapai sasaran organisasi, karena Total Quality Management (TQM) adalah pendekatan yang dapat dilakukan organisasi untuk meningkatkan daya saing perusahaan melalui perbaikan terus menerus terhadap produk, tenaga kerja, layanan, maupun lingkungan (Amanah, 2017, hal. 473).

Perusahaan sebagai salah satu bentuk organisasi pada umumnya memiliki tujuan tertentu yang ingin dicapai dalam usaha untuk memenuhi kepentingan para stakeholder. Manajemen mutu merupakan hal yang sangat penting untuk diterapkan dalam suatu organisasi/ perusahaan dalam meraih keunggulan kompetitif. Proses kerja yang efektif dan efisien diikuti oleh SDM yang berkompeten dan memiliki loyalitas dan daya juang yang tinggi. Berikutnya peningkatan kinerja dan berakhir pada kepuasan konsumen. Ketika kepuasan konsumen tercapai akan terjadi peningkatan pembelian secara multiply mengingat konsumen adalah marketer produk yang baik dan meningkatkan total revenue (Natha, 2008, hal. 2).

Optimalisasi dana pihak ketiga menjadi sangat penting dalam meningkatkan profitabilitas atau total revenue. Pertama, cukup signifikannya DPK yang berhasil dihimpun oleh lembaga pembiayaan syariah mengindikasikan bahwa kepercayaan masyarakat untuk menyimpan dana di lembaga pembiayaan syariah sudah cukup terlembagakan dengan baik. Ini tentunya merupakan modal sosial bagi lembaga pembiayaan syariah di Indonesia guna meningkatkan kinerja dan mutu pelayanannya. Kedua, cukup besarnya proporsi nilai DPK terhadap total aset menunjukkan bahwa keberadaan DPK menjadi unsur vital bagi kinerja operasional lembaga pembiayaan syariah. Penjelasan alur transmisinya, dana pihak ketiga (DPK) adalah unsur pembentukkan pendapatan karena dari DPK ini akan disalurkan dalam bentuk pembiayaan. Selanjutnya pembiayaan yang disalurkan tersebut akan diperoleh tingkat pengembalian berupa marjin. Selain itu, besarnya DPK juga berpengaruh positif terhadap penyaluran kredit. Ketika dana-dana yang terkumpul dari masyarakat tinggi, maka keputusan untuk menyalurkan kredit akan semakin tinggi pula (Fitri, 2016, hal. 74). 
Dibandingkan dengan peers group, BNI Syariah tercatat sebagai bank dengan Aset, Pembiayaan, dan DPK terbesar ketiga. Sepanjang tahun 2017 BNI Syariah mampu menjaga kualitas dan profitabilitas dengan baik, sehingga beberapa rasio penting jauh lebih baik dibandingkan industri (Laporan Tahunan BNI Syariah, 2017, hal. 136). Dengan adanya peningkatan DPK, Total Aset dan Pembiayaan yang dialami BNI Syariah selama 3 tahun terakhir, penulis meng-asumsikan bahwa BNI Syariah melakukan pengelolaan/ manajemen mutu yang baik disetiap tahunnya sehingga meningkatkan kepercayaan masyarakat dan berakhir pada peningkatan kinerja perusahaan. Untuk itu, penulis tertarik untuk melakukan penelitian untuk meneliti manajemen mutu yang diterapkan BNI Syariah sejak periode awal spin off (2010) hingga periode 2017, sehingga dari penerapan tersebut apakah terdapat dampak bagi kinerja keuangan BNI Syariah.

Tujuan dari penelitian ini adalah untuk menganalisis dampak manajemen mutu yang diterapkan BNI Syariah dalam meningkatkan kinerja keuangan BNI Syariah pada Periode 2010 hingga Periode 2017. Adapun penelitian terdahulu yang relevan dengan penelitian ini adalah penelitian yang dilakukan pada tahun 2010 oleh Salman D. Al-Shobaki, Rami H. Fouad, dan Adnan Al-Bashir dengan judul The Implementaton of Total Quality Management (TQM) for The Banking Sector in Jordan. Yang mana hasil penelitian tersebut menyatakan bahwa penerapan TQM di Jordanian perbankan sektor memimpin untuk meningkatkan produktivitas dan kemampuan untuk bersaing di pasar global.

Kemudian penelitian yang dilakukan pada tahun 2015 oleh Galih Fajar Muttaqin dan Rita Dharmayanti dengan judul Pengaruh Implementasi Total Quality Management terhadap Kinerja Keuangan dengan Kualitas Kinerja sebagai Variabel Intervening. Hasil dari penelitian tersebut adalah pelaksanaan TQM berpengaruh positif terhadap kinerja kualitas; kinerja kualitas memiliki pengaruh positif dengan kinerja keuangan; implementasi TQM berpengaruh langsung pada kinerja keuangan; serta kinerja kualitas menengahi TQM terhadap kinerja keuangan.

Dan penelitian yang dilakukan pada tahun 2016 oleh Christy M. Tumbel, Altje L. Tumbel, dan Indrie D. Palandeng dengan judul Penerapan Sitem Manajemen Mutu dalam Meningkatkan Kinerja Operasional Koperasi Simpan Pinjam (Studi Pada Koperasi Glaistygil Manado). Hasil penelitian tersebut menunjukkan bahwa sistem manajemen mutu di Koperasi Glaistygil telah berhasil meningkatkan kinerja operasional di Koperasi Simpan Pinjam Glaistygil Manado. Hal tersebut dilihat dari kualitas layanan, kualitas proses, kualitas organisasi, kualitas pemimpin, serta komitmen organisasi Glaistygil telah mengimplementasikan sistem manajemen mutu dengan baik. 
Jurnal Ekonomi dan Perbankan Syariah

Vol. 7. No.2, Agustus 2018: 83-106, ISSN (cet): 2355-1755 | ISSN (online): 2579-

6437

| 87

\section{LANDASAN TEORI}

1. Manajemen Mutu

Al Aqeeli (2001) mendefinisikan kualitas (mutu) sebagai "the organization's production of a commodity or provide a high quality service through which to meet the needs and desires of its customers in a way that is consistent with their expectations and achieve satisfaction and happiness, this is done through measures put in advance for the production of a distinctive good or service" (Basheer \& dkk, 2015, hal. 67). Sedangkan Manajemen adalah proses planning, organizing, actuating, dan controlling segala sumber daya yang dimiliki perusahaan (termasuk sumber daya manusia dan sumber daya lainnya guna mencapai tujuan secara efektif dan efisien (Arifin, 2016, hal. 186).

Dengan adanya persaingan ketat yang terjadi saat ini, maka sebuah organisasi/ perusahaan harus dapat mengendalikan sumber daya yang dimilikinya sehingga dapat menghasilkan barang/ jasa yang berkualitas, untuk itu diperlukanlah sistem manajemen mutu. Dengan penerapan suatu sistem mutu tertentu, tentunya akan memerikan dampak positif bagi perusahaan. Dengan penerapan ini diharapkan akan meningkatkan dan menjamin mutu dari produk atau layanan yang dihasilkan sehingga pada akhirnya akan meningkatkan kepuasan konsumen terhadap produk atau layanan yang disediakan. (Ismanto, 2009, hal. 11)

Nasution (2010) menjelaskan bahwa Total Quality Management (TQM) merupakan pendekatan dalam menjalankan usaha yang mencoba memaksimumkan daya saing organisasi melalui perbaikan terus menerus atas produk, jasa, manusia, proses dan lingkungannya. Untuk menghasilkan kualitas yang terbaik diperlukan upaya perbaikan berkesinambungan terhadap kemampuan manusia, proses dan lingkungan (Tumbel \& dkk, 2016, hal. 16). Manajemen Mutu terpadu atau disebut juga dengan Total Quality Management (TQM) dapat didefinisikan dari tiga kata yang dimilikinya, yaitu: total (keseluruhan), quality (kualitas, derajat/ tingkat keunggulan barang/ jasa), dan management (tindakan, seni, pengendalian, dan pengarahan). Kid Sadgrove (1995) menyatakan bahwa TQM adalah sistem manajemen yang berorientasi pada kepuasan pelanggan dengan kegiatan yang diupayakan dengan sungguhsungguh melalui perbaikan berkesinambungan (ipqi.org).

Tujuan yang akan dicapai dengan budaya Total Quality Management (TQM) adalah memenuhi atau bahkan melebihi apa yang dibutuhkan dan yang diharapkan oleh pelanggan sehingga tercipta prefensi masyarakat yang memilih lembaga keuangan masyarakat bukan hanya semata-mata karena agama, melainkan dari mutu (kualitas) yang dihasilkan oleh lembaga keuangan syariah tersebut (Ismanto, 2011, hal. 95). Selain itu, manfaat atas implementasi TQM dapat dirasakan bagi beberapa pihak (ipqi.org).

Manfaat TQM bagi nasabah/ pelanggan ialah sedikit atau bahkan tidak memiliki masalah dengan produk atau pelayanan, kepedulian terhadap nasabah/ pelanggan lebih baik, serta kepuasan pelanggan terjamin. Adapun 
manfaat TQM bagi institusi ialah terdapat perubahan kualitas produk dan pelayanan, produktivitas meningkat, biaya turun produk cacat berkurang, dan permasalahan dapat terselesaikan dengan cepat. Adapun manfaat TQM bagi staf/ karyawan organisasi ialah pemberdayaan, lebih terlatih dan berkemampuan, serta lebih dihargai dan diakui.

Pada bulan September 2015, ISO 9001:2015 mengubah delapan prinsip manajemen mutu pada ISO 9001 : 2008 menjadi tujuh prinsip. Ketujuh prinsip ini dikenal dengan jembatan keledai "CLEPIER" (customer focus, leadership, engagement of people, process approach, improvement, evidence based decision making, relationship management) (ipqi.org).

A. Fokus pada Pelanggan

Fokus utama manajemen mutu adalah guna memenuhi persyaratan pelanggan dan untuk berupaya melebihi harapan pelanggan. Tiap aspek interaksi pelanggan memberikan peluang untuk menciptakan nilai lebih kepada pelanggan. Pemahaman kebutuhan saat ini dan masa depan dari pelanggan memberikan sumbangsih kepada kesuksesan berkesinambungan dari organisasi.

\section{B. Kepemimpinan}

Pemimpin pada semua tingkatan menetapkan kesatuan sasaran dan arahan, serta menciptakan kondisi yang membuat semua orang terlibat dalam pencapaian sasaran mutu organisasi. Penciptaan kesatuan sasaran, arahan, dan pelibatan ini memungkinkan organisasi untuk menyelaraskan strategi, kebijakan, proses, dan sumber daya untuk mencapai sasaran organisasi.

C. Pelibatan Orang

Organisasi perlu memastikan semua orang kompeten, diberdayakan, dan dilibatkan dalam pemberian nilai organisasi. Orang-orang yang kompeten, diberdayakan, dan dilibatkan di seluruh organisasi akan meningkatkan kapasitas organisasi untuk menciptakan nilai. Untuk mengelola organisasi secara efektif dan efisien, semua orang pada semua orang perlu dilibatkan dan dihargai sebagai individu. Pengakuan, pemberdayaan, peningkatan keterampilan dan pengetahuan memfasilitasi pelibatan orang dalam pencapaian sasaran organisasi.

D. Pendekatan Proses

Hasil yang konsisten dan terprediksi dapat dicapai dengan lebih efektif dan efisien saat aktivitas dipahami dan dikelola sebagai proses yang saling terkait yang berfungsi sebagai suatu sistem yang terpadu. Sistem manajemen mutu terdiri atas proses yang saling terkait. Pemahaman bagaimana suatu keluaran dihasilkan oleh sistem ini, termasuk semua proses, sumber daya, pengendalian, dan interaksi, memungkinkan pengoptimalan kinerja organisasi. E. Perbaikan

Organisasi yang sukses terus-menerus menekankan pada perbaikan. Perbaikan penting bagi organisasi untuk memelihara tingkat kinerja saat ini, untuk menanggapi perubahan kondisi internal dan eksternal, serta untuk menciptakan peluang baru. 


\section{F. Pengambilan Keputusan Berdasarkan Bukti}

Keputusan berdasarkan analisis dan evaluasi data dan informasi lebih berpeluang untuk mencapai hasil yang diinginkan. Pengambilan keputusan dapat menjadi proses yang kompleks dan selalu melibatkan ketidakpastian. Proses ini kadang melibatkan beragam jenis dan sumber masukan, serta interpretasi terhadap masukan tersebut, yang dapat bersifat subjektif. Diperlukan pemahaman terhadap hubungan sebab dan akibat serta potensi dampak yang tidak diinginkan. Fakta, bukti, dan analisis data meningkatkan objektivitas dan kepercayaan dalam pengambilan keputusan.

G. Manajemen Hubungan

Guna mencapai kesuksesan yang berkesinambungan, organisasi mengelola hubungannya dengan para pemangku kepentingan, seperti pemasok. Pemangku kepentingan memengaruhi kinerja organisasi. Pengelolaan hubungan dengan para pemangku kepentingan ini mengoptimalkan pengaruh mereka terhadap kinerja organisasi. Manajemen hubungan dengan pemasok dan jaringan mitra seringkali memiliki kepentingan tertentu.

Hal yang terpenting dalam TQM adalah seberapa besar pengaruh dari TQM tersebut dapat meningkatkan mutu dari perusahaan jasa/ suatu lembaga keuangan syariah. Hal ini perlu dilakukan agar lembaga keuangan syariah dapat menciptakan suatu produk maupun pelayanan yang memuaskan bagi masyarakat, sehingga masyarakat dapat memilih bank syariah karena mutu yang dihasilkan oleh lembaga keuangan syariah tersebut. Berikut adalah komitmen kualitas dalam TQM yang dapat dijadikan sebagai konsep dari pelaksanaan TQM di suatu perusahaan jasa/ lembaga keuangan syariah (Ismanto, 2009, hal. 137). 
Bagan 1.1 Komitmen Kualitas dalam TQM

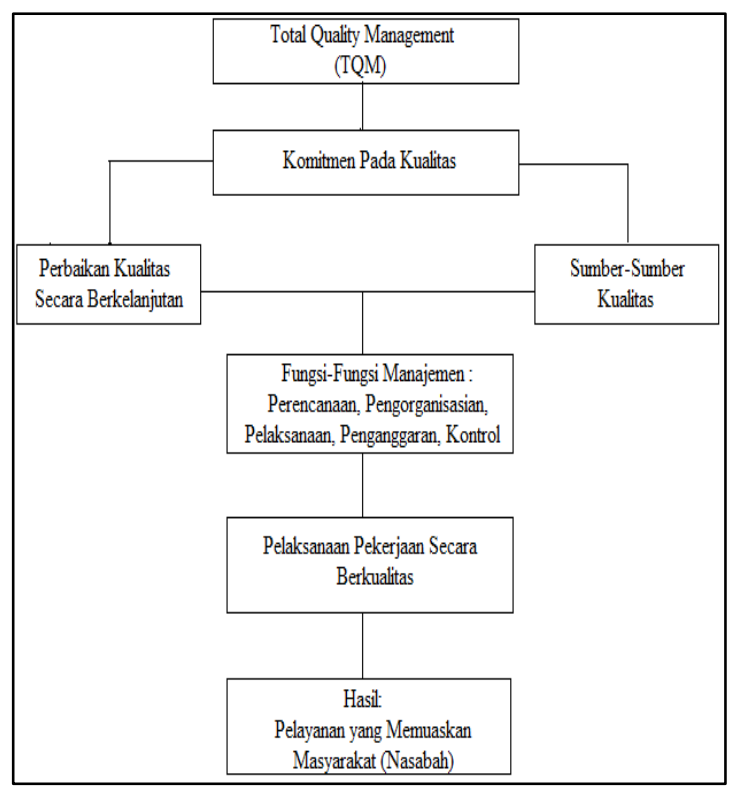

Sumber: Ismanto, 2009, hlm. 142

Pada Bagan di atas, Ismanto telah menjelaskan bagaimanan konsep yang harus dilakukan pada lembaga keuangan syariah/ perusahaan jasa. Hal yang pertama yang harus diterapkan dalam sebuah perusahaan jasa/ lembaga keuangan syariah ialah komitmen pada kualitas. Dilanjutkan pada proses perbaikan kualitas yang berkelanjutan, dan didukung dengan sumber-sumber yang bekualitas.

Hal tersebut akan menjadi pertimbangan manajemen dalam pengambilan keputusan, yang mana nantinya pihak manajemen merumuskan rencana-rencana dan menetapkan kebijakan didalam sebuah perusahaan jasa/ lembaga keuangan syariah. Kebijakan tersebut haruslah dilaksanakan oleh seluruh elemen di dalam sebuah perusahaan sehinga dapat menghasilkan kepuasan nasabah.

\section{Kinerja Keuangan}

Siegel dan Shim (1994) menjelaskan bahwa kinerja (performance) dalam kamus istilah akuntansi adalah kuantifikasi dari keefektifan dalam pengoperasian bisnis selama periode tertentu. Kinerja perusahaan dapat diukur dengan menganalisa dan mengevaluasi laporan keuangan. Informasi posisi keuangan dan kinerja keuangan di masa lalu seringkali digunakan sebagai dasar untuk memprediksi posisi keuangan dan kinerja di masa depan dan halhal lain yang langsung menarik perhatian pemakai seperti pembayaran dividen, upah, pergerakan harga sekuritas dan kemampuan perusahaan untuk memenuhi komitmennya ketika jatuh tempo (Kusumo, 2008, hal. 111). 
Adyani (2011) memaparkan bahwa kinerja keuangan bank merupakan gambaran kondisi keuangan bank pada suatu periode tertentu baik mencakup aspek penghimpunan dana maupun penyaluran dananya. Kinerja menunjukkan sesuatu yang berhubungan dengan kekuatan serta kelemahan suatu perusahaan. Kekuatan tersebut dipahami agar dapat dimanfaatkan dan kelemahan pun harus diketahui agar dapat dilakukan langkah-langkah perbaikan. Penilaian terhadap kinerja suatu bank dapat dilakukan dengan melakukan analisis terhadap laporan keuangnya (Yunia dan Kartika, 168).

Penilaian kinerja keuangan terhadap kemampuan bank syariah untuk menghasilkan laba sangat bermanfaat bagi bank dan mitra bank. Dengan melihat tren kinerja keuangan mitra bank syariah dapat memutuskan model kebijakan kemitraan dengan bank (Sudarsono, 2017, hal. 182).

Pengukuran kinerja merupakan suatu cara memantau dan mengukur kemajuan yang sudah dicapai atas tujuan-tujuan strategis yang telah diciptakan (Imelda, 2004, hal. 114-115). Menurut Mawaddah (2015), keuntungan dengan membaca laporan ini pihak manajemen dapat memperbaiki kelemahan yang ada serta mempertahankan kekuatan yang dimilikinya (hal. 245).

Kinerja sebuah perusahaan lebih banyak di ukur berdasarkan rasio-rasio keuangan selama satu periode tertentu. Laporan keuangan bank menunjukkan kondisi keuangan bank secara keseluruhan. Laporan ini juga menunjukkan kinerja manajemen bank selama satu periode (Mawaddah, 2015, hal. 245).

Menurut PBI No. 9/1/PBI/2007 Tingkat Kesehatan Bank merupakan hasil penilaian kualitatif atas berbagai aspek yang berpengaruh terhadap kondisi atau kinerja bank dengan melakukan penilaian terhadap faktor finansial dan faktor manajemen. Peraturan tersebut merupakan regulasi mengenai pengukuran tingkat kesehatan bank melalui metode CAMELS. Dalam regulasi tersebut, faktor-faktor yang menjadi pengukuran kinerja keuangan suatu lembaga keuangan ialah Capital (modal), Asset (aset), Management (manajemen), Earning (profitabilitas), serta Sensitivity to Market Risk (sensitivitas terhadap risiko pasar).

Kemudian pada Tahun 2014, lahirlah POJK No. 8/POJK.03/ 2014 yang merupakan regulasi terbaru dalam pengukuran tingkat kesehatan bank. Dalam regulasi tersebut, pengukuran tingkat kesehatan bank dapat dilakukan melalui metode RGEC yang terdiri dari empat faktor, yaitu: Profil Risiko (risk profile) yang merupakan penilaian terhadap profil risiko merupakan penilaian terhadap risiko inheren dan kualitas penerapan kualitas penerapan manajemen risiko dalam operasional bank yang dilakukan terhadap 10 risiko, yaitu: Risiko Kredit, Risiko Pasar, Risiko Likuiditas, Risiko Operasional, Risiko Hukum, Risiko Stratejik, Risiko Kepatuhan, Risiko Reputasi, Risiko Imbal Hasil, dan Risiko Investasi; Tata Kelola Perusahaan (Good Corporate Governance), yaitu penilaian terhadap faktor Good Corporate Governance merupakan penilaian terhadap manajemen Bank Umum Syariah atas pelaksanaan prinsip-prinsip Good Corporate Governance; Rasio Rentabilitas, yaitu penilaian terhadap faktor rentabilitas meliputi penilaian terhadap kinerja rentabilitas, sumber- 
sumber rentabilitas, dan stabilitas rentabilitas; serta Rasio Permodalan yang merupakan penilaian pada faktor permodalan meliputi penilaian penilaian terhadap tingkat kecukupan permodalan dan pengelolaan permodalan Bank Umum Syariah.

\section{Metode Penelitian}

\section{A. Jenis dan Sumber Data}

Jenis data dan analisis yang digunakan dalam penelitian ini bersifat kualitatif dengan studi kasus BNI Syariah. Adapun untuk jenis analisis pada penelitian ini bersifat deskriptif. Sumber data yang digunakan pada penelitian ini adalah sumber primer dan sumber sekunder.

Penulis melakukan wawancara terstruktur dengan Operational Head BNI Syariah Cabang Depok, adapun untuk wawancara tidak terstruktur dilakukan diskusi dengan divisi Change Management Office (CMO) BNI Syariah Pusat. Sedangkan untuk pengumpulan data lainnya penulis menggunakan Laporan Tahunan BNI Syariah periode 2010 hingga periode 2017 serta bahan-bahan penelitian lainnya, seperti buku-buku ilmiah, berbagai penelitian terdahulu (seperti skripsi, disertasi, tesis, maupun jurnal), situs resmi lembaga milik pemerintah untuk mendapatkan informasi yang tidak penulis dapatkan secara langsung di lapangan.

B. Teknik Analisis Data

Teknik analisis data yang digunakan pada penelitian ini menggunakan analisis perbandingan laporan keuangan, yaitu teknik analisis dengan cara membandingkan laporan keuangan dari dua periode atau lebih untuk menunjukkan perubahan dalam jumlah (absolut) maupun persentase (relatif) (Hery, 2015, hal. 29).

Penelitian ini betujuan untuk mengukur rasio kecukupan modal, rasio kemampuan perusahaan dalam menghasilkan profit (rentabilitas), serta rasio kemampuan perusahaan dalam memenuhi kewajiban (likuiditas), yang mana penilaian kinerja keuangan tersebut mengacu pada Lampiran Surat Edaran No. 9/24/DPbS sebagai tolak ukur pada penelitian ini. Adapun penjelasan mengenai faktor-faktor yang menjadi penilaian pada penelitian ini adalah:

\section{a. Rasio Kecukupan Modal}

Rasio permodalan ini berfungsi untuk mengukur kemampuan bank dalam menyerap kerugian-kerugian yang tidak dapat dihindari lagi serta dapat pula digunakan untuk mengukur besar-kecilnya kekayaan bank tersebut atau kekayaan yang dimiliki oleh para pemegang sahamnya. (Kusumo, 2008, hal. 112). KPMM merupakan rasio keuangan yang dapat digunakan dalam menghitung kemampuan modal untuk menyerap kerugian dan pemenuhan ketentuan KPMM yang berlaku. Adapun rumus dari KPMM adalah:

$$
\frac{\text { Modal }}{\text { ATMR }} \text { X } 100 \%
$$

\section{Kriteria penilaian peringkat:}

a. Peringkat 1: $\mathrm{KPMM} \geq 12 \%$

b. Peringkat 2: $9 \% \leq \mathrm{KPMM}<12 \%$ 
Jurnal Ekonomi dan Perbankan Syariah

Vol. 7. No.2, Agustus 2018: 83-106, ISSN (cet): 2355-1755 | ISSN (online): 2579-

6437

193

c. Peringkat 3: $8 \% \leq \mathrm{KPMM}<9 \%$

d. Peringkat $4: 6 \%<\mathrm{KPMM}<8 \%$

e. Peringkat 5 : $\mathrm{KPMM} \leq 6 \%$

b. Rasio Rentabilitas

Rasio rentabilitas merupakan alat untuk menganalisis atau mengukur tingkat efisiensi usaha dan kemampuan bank dalam menghasilkan laba (Kusumo, 2008, hal. 112).

Net Operational Margin (NOM)

Adalah rasio yang bertujuan untuk mengetahui kemampuan aktiva produktif dalam menghasilkan laba (Surat Edaran Bank Indonesia No. 9/24/DPbS, 2007). Adapun rumus untuk menghitung rasio NOM adalah :

$$
\frac{(\text { Pendapatan Operasional - Distribusi Bagi Hasil) - Biaya Operasional }}{\text { Rata - Rata Aktiva Produktif }}
$$

\section{Kriteria penilaian peringkat:}

a. Peringkat $1=\mathrm{NOM}>3 \%$

b. Peringkat $2=2 \%<\mathrm{NOM} \leq 3 \%$

c. Peringkat $3=1,5 \%<\mathrm{NOM} \leq 2 \%$

d. Peringkat $4=1 \%<\mathrm{NOM} \leq 1,5 \%$

e. $\quad$ Peringkat $5=\mathrm{NOM} \leq 1 \%$

\section{Return On Asset (ROA)}

Return on Aset (ROA) atau profitabilitas merupakan rasio yang digunakan untuk mengukur efektivitas manajemen dalam mengelola besaran laba yang diperoleh bank. ROA digunakan untuk mengetahui kemampuan bank dalam mengelola aset untuk menghasilkan laba secara maksimal (Sudarsono, 2017, hal. 175). Rumus untuk menghitung ROA adalah:

$$
\frac{\text { Laba Sebelum Pajak }}{\text { Rata-Rata Total Aset }} \text { X } 100 \%
$$

\section{Kriteria penilaian peringkat:}
a. Peringkat 1 : $\mathrm{ROA}>1,5 \%$
b. Peringkat 2 : $1,25 \%<\mathrm{ROA} \leq 1,5 \%$
c. Peringkat 3 : $0,5 \%<\mathrm{ROA} \leq 1,25 \%$
d. Peringkat $4: 0 \%<\mathrm{ROA} \leq 0,5 \%$
e. Peringkat 5 : $\mathrm{ROA} \leq 0 \%$

Return On Equity (ROE) 
94 | Galuh Gita Pratiwi, Nur S.Buchori, Mustafa Kamal : Penerapan Manajemen Mutu dalam Meningkatkan Kinerja Keuangan BNI Syariah Periode 2010-2017

Return On Equity (ROE) merupakan rasio keuangan yang digunakan untuk mengukur tingkat profitabilitas dari ekuitas. Semakin besar hasil ROE maka kinerja perusahaan semakin baik (Veno \& Syamsudin, 2016, hal. 7). Semakin besar rasio ini menunjukkan kemampuan modal disetor bank dalam menghasilkan laba bagi pemegang saham semakin besar. Rumus untuk menghitung ROE adalah: (Surat Edaran Bank Indonesia No. 9/24/DPbS, 2007)

$$
\frac{\text { Laba Sesudah Pajak }}{\text { Rata-Rata Modal Disetor }} \text { X } 100 \%
$$

\section{c. Rasio Likuiditas}

Penilaian likuiditas dimaksudkan untuk menilai kemampuan bank dalam memelihara tingkat likuiditas yang memadai termasuk antisipasi atas risiko likuiditas yang akan muncul (Surat Edaran Bank Indonesia No. 9/24/DPbS, 2007).

\section{Short Term Mismatch (STM)}

Adalah rasio yang bertujuan untuk Mengukur kemampuan bank dalam memenuhi kebutuhan likuiditas jangka pendek.

$$
\frac{\text { Aktiva Jangka Pendek }}{\text { Kewajiban Jangka Pendek }}
$$

\section{Kriteria penilaian peringkat:}
a. Peringkat $1: \mathrm{STM}>25 \%$
b. Peringkat $2: 20 \%<\mathrm{STM} \leq 25 \%$
c. Peringkat $3: 15 \%<\mathrm{STM} \leq 20 \%$
d. Peringkat $4: 10 \%<\mathrm{STM} \leq 15 \%$
e. Peringkat 5 : $\mathrm{STM} \leq 10 \%$

\section{PEMBAHASAN}

Berdasarkan laporan tahunan yang dipublikasikan, PT BNI Tbk mendapatkan banyak mendapatkan penghargaan ISO 9000 mengenai Quality Management di perusahaan tersebut. Pada tahun 1999, BNI berhasil memperoleh sertifikat ISO 9002 sebagai pengakuan standar kualitas yang meliputi Unit Pemrosesan Bersama (UPB). Berlanjut pada tahun 2007, PT BNI Tbk meraih Century ERA Award di Bidang Total Quality Management serta 3 sertifikat ISO 9001:2000 dibidang Informasi Teknologi. Kemudian pada tahun berikutnya (2008), PT BNI Tbk juga menerima sertifikat International Quality Crown Award, di London untuk kategori Customer Satisfaction, Leadership, Innovation and Efficiency as established in the QC100 TQM model. Adanya penghargaan ini membuktikan bahwa PT BNI Tbk selalu menjaga mutu dalam hal proses maupun layanan yang diberikan kepada para nasabah.

Berdasarkan halaman resmi BNI Syariah, pada akhir Desember 2016, PT BNI Tbk memperoleh sertifikasi ISO 9001:2015 atas standarisasi kualitas 
Jurnal Ekonomi dan Perbankan Syariah

Vol. 7. No.2, Agustus 2018: 83-106, ISSN (cet): 2355-1755 | ISSN (online): 25796437

\section{5}

proses dan layanan yang diterapkan. BNI Syariah merupakan bagian dari PT BNI Tbk (Unit Usaha Syariah) sebelum melakukan spin off dan beroperasi menjadi Bank Umum Syariah pada pertengahan tahun 2010. Menginduk pada perusahaan tersebut, penulis berasumsi bahwa BNI Syariah mengadopsi penerapan manajemen mutu/ kualitas dari PT BNI Tbk sejak awal perkembangan BNI Syariah menjadi Bank Umum Syariah. Hal ini didasarkan pada pernyataan BNI Syariah tahun 2015 yang menyatakan bahwa, BNI Syariah memanfaatkan sertifikasi layanan dan teknologi yang dimiliki oleh PT Bank BNI (Persero) Tbk yang telah mendapatkan penghargaan dari ISO 9001:2008. Berdasarkan hasil diskusi yang telah dilakukan dengan CMO BNI Syariah Pusat, penulis menyimpulkan bahwa BNI Syariah telah menjalankan prinsip-prinsip Total Quality Management (TQM) akan tetapi secara resmi, BNI Syariah belum melegalkan hal tersebut.

Periode 2010 pengembangan kualitas layanan/ mutu difokuskan pada teknologi informasi melalui pengembangan Core Banking System. Selain itu, BNI Syariah juga berfokus pada peningkatan layanan dari sisi teknologi dan kemudahan transaksi. Untuk meningkatkan transaksional, pada tahun 2011 BNI Syariah telah meningkatkan pengamanan transaksi melalui Internet Banking dengan demikian nasabah dapat melakukan transaksi pembayaran setiap saat (24 jam 7 hari) dengan aman.

Pada tahun 2012, Electronic Financing Origination (EFO) System Micro Banking telah dibangun secara insourcing. Penggunaan sistem EFO Micro Banking terbukti dapat mempercepat proses sekaligus melakukan mitigasi risiko dalam proses pemberian pembiayaan mikro. Dalam meningkatan kualitas layanan kepada konsumen, pada tahun 2013 BNI Syariah mulai menetapkan standar layanan yang disebut GREAT (Greeting, Relationship, Emphaty, Attention, dan Trust) ) sebagai standar layanan yang berlaku bagi semua karyawan BNI Syariah.

Kemudian, salah satu bentuk komitmen BNI Syariah dalam meningkatkan kualitas layanan adalah dengan membentuk Service Desk pada awal tahun 2016. Dan pada tahun 2017, BNI Syariah melakukan pengembangan BNI Syariah Call Center dalam rangka meningkatkan kualitas layanan melalui telepon dan mempercepat waktu penyelesaian pengaduan nasabah, juga peningkatan kualitas dilakukan pada salah satu unit di divisi operasional dalam hal penanganan kejahatan digital $e$-banking, yang menjadi bagian dari fungsi unit $e$-banking yang mengelola investigasi.

Kepuasan nasabah merupakan tolak ukur dalam meningkatkan kualitas layanan dan pengembangan produk jasa BNI Syariah. Upaya peningkatan kualitas layanan dilakukan secara berkala melalui penilaian dari pihak eksternal maupun internal serta membangun budaya layanan kepada seluruh Insan Hasanah BNI Syariah. Analisa lingkungan bisnis terkait layanan melalui survei kepuasaan nasabah dilakukan untuk pengembangan layanan yang dilakukan oleh BNI Syariah secara berkala melalui "Program Survei Kepuasan Nasabah". Pengukuran Service Delivery and Process secara mandiri terhadap 
$\mathrm{KC} / \mathrm{KCP} / \mathrm{KK} / \mathrm{KCM}$ juga dilakukan BNI Syariah melalui proyek mystery shopper. Hal ini menjadikan tolak ukur bagi BNI Syariah untuk mengevaluasi pelayanan maupun produk yang diberikan.

Dalam hal lain, untuk pengambilan keputusan berdasarkan bukti serta perbaikan secara berkelanjutan, BNI Syariah menetapkan sistem pemantauan pencapaian target melalui Performance Measurement System yang difokuskan kepada Key Performance Indicator. Sehingga dengan adanya hal tersebut, maka pihak manajemen dapat mengevaluasi dan menentukan keputusan yang akan diambil untuk menghasilkan produk maupun pelayanan yang lebih baik lagi.

Dalam prinsip perbaikan berkelanjutan juga diterapkan oleh Kantor Cabang BNI Syariah dengan mengadakan briefing pagi untuk mengevaluasi kinerja setiap harinya dan melakukan inovasi atau perbaikan untuk hal-hal yang diperlukan, seperti layanan kepada nasabah maupun operasionalnya. Selain itu, adanya head discussion yang diadakan dalam jangka waktu seminggu sekali, hal ini diperuntukkan bagi karyawan yang menjabat sebagai kepala divisi (head division) untuk pencapaian kinerja, mendiskusikan kendala yang terjadi di Cabang, dan pembahasan lainnya.

Pada aspek pengelolaan hubungan, sejak periode 2011, BNI Syariah telah berfokus untuk membangun kemitraan guna saling bersinergi untuk mencapai kemakmuran. Adapun pengelolaan hubungan dengan nasabah yang dilakukan oleh BNI Syariah ialah dengan membangun kerangka program loyalitas nasabah melalui customer experience day yang bertepatan pada Milad BNI Syariah dan Hari Besar Islam.

Sumber daya manusia merupakan 'bahan bakar' organisasi dalam menjalankan aktivitas perusahaan. Untuk menciptakan produk maupun pelayanan yang berkualitas, maka SDM yang dimiliki perusahaan haruslah memiliki skill maupun pengetahuan yang mumpuni. Dalam aspek pengembangan SDM, BNI Syariah mengadakan beberapa program seperti pelatihan dan pengembangan bagi karyawan dengan mengimplementasikan program Talent Management untuk mendorong capability development pegawai juga program Bina Hasanah (pelatihan berbasis teori dan praktik secara langsung di bawah bimbingan pegawai BNI Syariah). BNI Syariah juga mengadakan sertifikasi manajemen risiko mulai dari jenjang junior manager sampai dengan executive manager; Assistant Development Program (ADP) dan Officer Development Program (ODP).

Pada tahun 2012, BNI Syariah mengembangkan Human Resources Information System (HRIS) berbasis kompetensi untuk mendukung kinerja human capital yang terintegrasi. Seiring perkembangan zaman, pada tahun 2015, penggunaan HRIS diarahkan untuk optimalisasi kegiatan operasional kepegawaian seperti penggajian dan pendataan pegawai, termasuk proses rotasi/ mutasi/ promosi serta monitoring proses penyelesaian kasus pelanggaran disiplin pegawai.

Pengembangan keterampilan dan skill para karyawan juga dilakukan di seluruh Cabang BNI Syariah. Dengan mengadakan role play atau sharing session yang diadakan setiap satu bulan sekali. Sharing session tersebut 
dilakukan sebagai ajang sharing yang dilakukan pimpinan kepada seluruh karyawan yang berada di bawah tanggung jawab kantor Cabang BNI Syariah. Hal ini akan menjadikan pengetahuan atau wawasan seluruh karyawan menjadi meningkat. Semakin sering FGD dilakukan, maka semakin terlibat pula para karyawan. Prayogo dan Brown (2004) menyatakan bahwa pemberdayaan karyawan yang diikuti dengan keterlibatan karyawan secara total merupakan salah satu elemen kunci keberhasilan implementasi TQM dalam organisasi. (Munizu, 2010, hal. 191-192)

Hal tersebut merupakan bentuk manajemen sumber daya manusia yang ada di BNI Syariah. Menurut penelitian yang telah dilakukan Munizu (2011), hasil indikator manajemen sumber daya manusia berpengaruh positif dengan kinerja karyawan. Dari penelitian tersebut, dapat disimpulkan bahwa semakin efektif manajemen sumber daya manusia yang dilakukan di suatu perusahaan, maka hal tersebut akan meningkatkan skill atau kinerja karyawan di perusahaan tersebut dan berakhir pada peningkatan kinerja perusahaan.

Untuk mengukur kinerja manajemen BNI Syariah, divisi Human Capital Development (HCD) melakukan Employee Opinion Survey (EOS) yang ditujukan kepada seluruh karyawan BNI Syariah. Untuk penilaian kepemimpinan yang ada di BNI Syariah, dari 2.255 karyawan BNI Syariah, sebanyak $11,3 \%$ menyatakan sangat setuju dan $75,48 \%$ menyatakan setuju bahwa pimpinan di BNI Syariah mampu membangun suasana kerja yang profesional sehingga tercapai hasil kinerja yang melebihi target. Lalu, dari 2.255 karyawan BNI Syariah, 11,44\% sangat setuju dan 77,21\% setuju bahwa pimpinan di BNI Syariah selalu bersedia membantu karyawan yang mengalami kesulitan pada pekerjaannya. Selanjutnya, dari 2.255 karyawan BNI Syariah, sebanyak $11,00 \%$ menyatakan sangat setuju dan $77,07 \%$ menyatakan setuju bahwa pimpinan di BNI Syariah memiliki kemampuan yang baik dalam pengambilan keputusan.

Selanjutnya, dari 2.255 karyawan BNI Syariah, sebanyak 10,87\% menyatakan sangat setuju dan 76,54\% menyatakan setuju bahwa pimpinan di BNI Syariah mampu membentuk dan membina kerja sama antar karyawan di unit kerja/bisnis yang dipimpinnya. Dan 11,26 sangat setuju serta 78,58\% menyatakan setuju bahwa pimpinan BNI Syariah mampu memberikan arahan dan bimbingan yang baik. Cara membangun komunikasi antar pimpinan dengan karyawan lainnya adalah dengan agenda "Manajemen Menyapa" yaitu Direksi mengunjungi cabang-cabang di BNI Syariah yang selain untuk melakukan pengawasan kepada cabang juga untuk menyampaikan visi misi manajemen kepada pegawai di cabang.

Selain itu, adanya peran DPS yang dilibatkan untuk meninjau aspekaspek syariah baik dalam hal akad, penerbitan/ pengembangan sebuah produk, SOP maupun kebijakan, adalah hal yang diterapkan oleh BNI Syariah untuk menghasilkan suatu produk maupun pelayanan yang berkualitas dan tetap berada pada koridor syariat Islam. 
Dari beberapa penjabaran mengenai manajemen mutu yang diterapkan oleh BNI Syariah. Penulis mencoba untuk melihat dampak dari penerapan manajemen mutu terhadap kinerja keuangan di BNI Syariah. Adapun rasio yang diukur adalah rasio kecukupan modal, rasio kemampuan perusahaan dalam menghasilkan earning (rentabilitas) dan juga rasio kemampuan perusahaan dalam memenuhi kewajibannya (likuiditas). Berikut adalah gambaran perbandingan kinerja keuangan BNI Syariah periode 2010 dan periode 2017.

A. Rasio Kecukupan Modal

\section{Grafik 4.1 Persentase KPMM BNI Syariah Periode 2010 - 2017}

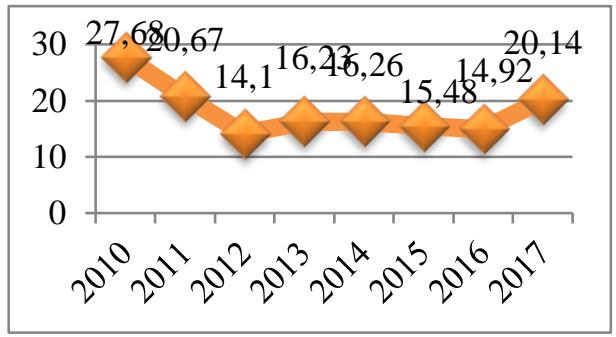

Sumber : Laporan Tahunan BNI Syariah Periode 2010 - 2017 (Data diolah)

Berdasarkan grafik 4.1, dapat kita lihat bahwa pada 3 tahun pertama mengalami penurunan rasio KPMM dan pada tahun-tahun berikutnya, rasio KPMM BNI Syariah berjalan stabil, dan mengalami kenaikan yang signifikan pada periode 2016 ke 2017. Berdasarkan PBI No. 9/1/PBI/2007 dapat kita amati bahwa seluruh angka rasio KPMM menduduki peringkat 1, yaitu nilai KPMM > 12\%. Selain itu, berdasarkan pengamatan melalui laporan tahunan, angka rata-rata persentase KPMM tersebut lebih tinggi dari rasio kecukupan minimum yang ditetapkan oleh OJK. Selain untuk mengantisipasi kerugian yang mungkin akan dialami, rasio KPMM yang berada di atas batas kecukupan minimum yang ditetapkan oleh OJK merupakan salah satu bentuk kepatuhan terhadap regulasi yang ada di Indonesia. Adanya hal tersebut, menandakan bahwa struktur permodalan BNI Syariah memiliki kapabilitas untuk mengimbangi risiko pasar, risiko kredit, dan risiko operasional.

Adanya penurunan persentase KPMM BNI Syariah terjadi karena kenaikan jumlah modal perusahaan diimbangi dengan kenaikan Aset Tertimbang Menurut Risiko (ATMR) yang terjadi. Adapun penurunan angka KPMM yang terjadi pada 3 tahun pertama pasca spin off, penulis berasumsi bahwa penurunan rasio KPMM tersebut dikarenakan ekspansi usaha yang dilakukan oleh BNI Syariah, sehingga porsi modal yang seharusnya digunakan untuk menyerap kerugian, dialihkan sebagai modal untuk usaha. Selain itu, peningkatan pembiayaan yang dilakukan oleh BNI Syariah juga menjadi alasan penurunan rasio KPMM pada 3 tahun pertama yaitu untuk menghasilkan earning/ profit bagi perusahaan. 
Jurnal Ekonomi dan Perbankan Syariah

Vol. 7. No.2, Agustus 2018: 83-106, ISSN (cet): 2355-1755 | ISSN (online): 2579-

6437

| 99

B. Rasio Rentabilitas

a. $\quad$ Net Operating Margin (NOM)

Grafik 4.2 Persentase NOM BNI Syariah Periode 2010 - 2017

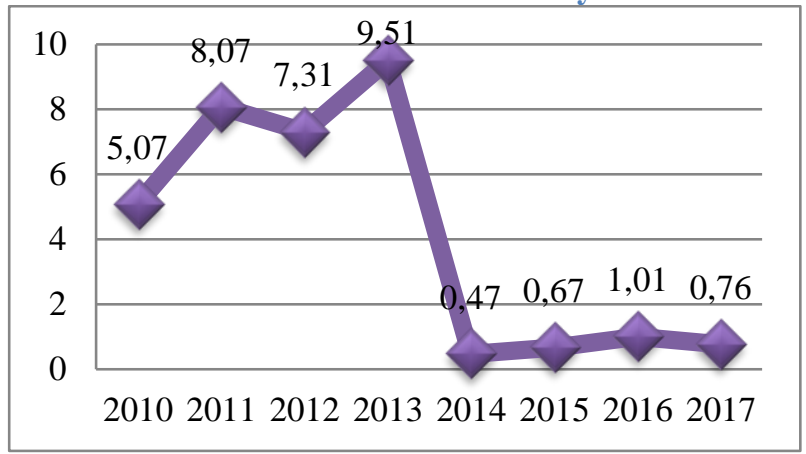

Sumber : Laporan Tahunan BNI Syariah Periode 2010 - 2017 (Data diolah)

Dari grafik 4.2 diatas dapat kita lihat bahwa terjadi penurunan rasio NOM yang sangat signifikan terjadi 2013 ke periode 2014 yang juga merupakan titik tertinggi dan terendah untuk rasio ini. Pada periode 4 tahun pertama, rasio NOM termasuk kategori sangat baik, karena berada diatas $4 \%$ dan menduduki peringkat 1 . Akan tetapi, pada periode 4 tahun setelahnya, angka rasio NOM termasuk kedalam kategori kurang, hal ini dikarenakan angka rasio NOM pada periode 2014 hingga 2017 rata-rata kurang dari $1 \%$. Namun secara keseluruhan, rasio NOM berada angka rata-rata $4,11 \%$.

Semakin tinggi angka persentase NOM, maka semakin baik, karena jumlah pendapatan bersih yang dihasilkan dari kegiatan operasional perusahaan lebih tinggi. Hal tersebut akan membuat masyarakat maupun pemilik saham menjadi lebih percaya kepada sebuah perusahaan karena dapat menghasilkan margin yang tinggi.

b. Return On Assets (ROA)

Grafik 4.3 Persentase ROA BNI Syariah Periode 2010 - 2017

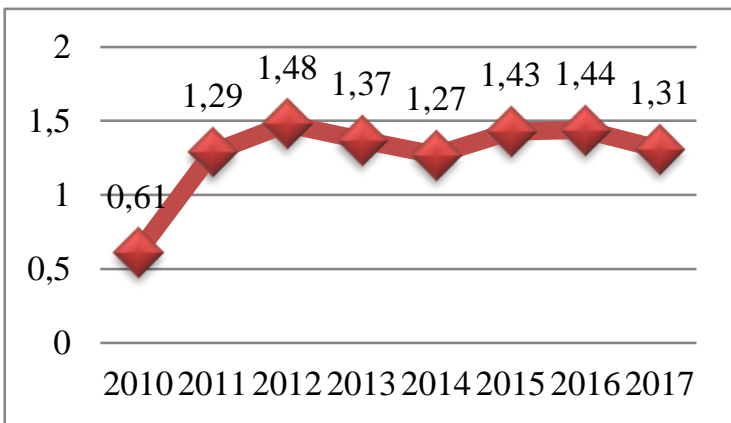

Sumber : Laporan Tahunan BNI Syariah Periode 2010 - 2017 (Data diolah) 
100 | Galuh Gita Pratiwi, Nur S.Buchori, Mustafa Kamal : Penerapan Manajemen Mutu dalam Meningkatkan Kinerja Keuangan BNI Syariah Periode 2010-2017

Berdasarkan grafik 4.3, dapat kita lihat bahwa pergerakan persentase ROA yang terjadi sejak periode 2010 hingga periode 2017 cenderung stabil. Persentase ROA tertinggi terjadi pada tahun 2012 yaitu sebesar 1,48\% dan persentase ROA terendah terjadi pada tahun 2010 yaitu sebesar $0,61 \%$.

Pergerakan persentase ROA yang terjadi pada periode 2010 hingga 2017 berada pada posisi yang stabil, hal ini menandakan bahwa BNI Syariah mampu mengelola, menjaga, serta menempatkan aset yang dimilikinya dengan baik, sehingga dari penerapan manajemen mutu yang dilakukan, aset yang dibukukan oleh BNI Syariah mampu meningkat disetiap tahunnya, sehingga kualitas aset yang dimiliki perusahaan mampu memberikan laba yang signifikan sepanjang periode 2010 hingga 2017.

\section{c. Return On Equity (ROE)}

Grafik 4.4 Persentase ROE BNI Syariah Periode 2010 - 2017

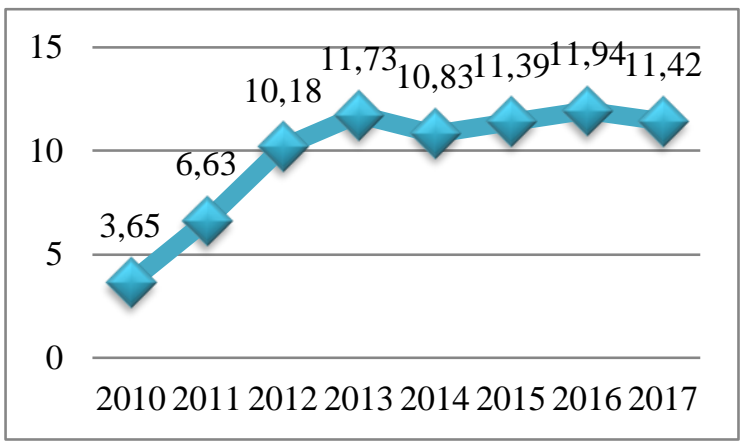

Sumber: Laporan Tahunan BNI Syariah Periode 2010 - 2017 (Data diolah)

Berdasarkan grafik 4.4. persentase ROE meningkat sejak periode 2010 hingga 2013 dan pada tahun-tahun berikutnya cenderung stabil. Nilai ROE tertinggi terjadi pada tahun 2016 yaitu sebesar 11,94\% dan persentase ROE terendah terjadi pada tahun 2010 , namun terjadi peningkatan pada tahun-tahun berikutnya. Pergerakan persentase ROE sejak periode 2010 - 2017 yang cenderung stabil disebabkan meningkatnya laba bersih di ikuti dengan modal disetor yang cenderung stagnan. Semakin besar nilai ROE, maka semakin baik pengelolaan modal yang disetorkan oleh para pemiliki modal kepada suatu perusahaan untuk menghasilkan keuntungan (return).

Dari pergerakan persentase ROE tersebut, penulis menyimpulkan bahwa BNI Syariah mampu dalam mengelola ekuitas yang percayakan oleh para pemilik modal kedalam aset-aset yang berkualitas untuk menghasilkan keuntungan (return). Hal tersebut (peningkatan ROE) akan menguatkan kepercayaan para pemilik modal kepada BNI Syariah dalam mengelola modal yang mereka setorkan. 
Jurnal Ekonomi dan Perbankan Syariah

Vol. 7. No.2, Agustus 2018: 83-106, ISSN (cet): 2355-1755 | ISSN (online): 2579-

6437

| 101

C. Rasio Likuiditas

Grafik 4.5 Persentase STM BNI Syariah Periode 2010 - 2017

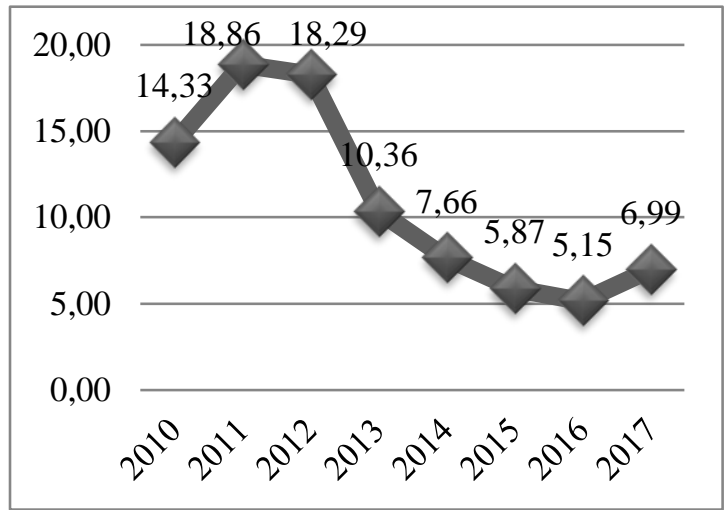

Sumber: Laporan Tahunan BNI Syariah Periode 2010 - 2017 (Data diolah)

Berdasarkan Grafik 4.5, dapat kita lihat persentase Short Term Mismatch (STM) BNI Syariah pada periode 2010 hingga periode 2017 cenderung mengalami penurunan. Persentase STM tertinggi terjadi pada tahun 2012, dan terendah terjadi pada tahun 2016 yang kemudian meningkat di tahun selanjutnya, 2017. Semakin besar persentase STM yang dihasilkan oleh suatu perusahaan, hal tersebut mengindikasikan bahwa kemampuan perusahaan untuk memenuhi kewajiban lancarnya semakin baik.

Berdasarkan lampiran SE-OJK No.9/24/2007, aktiva lancar dan liabilitas lancar yang diperhitungkan adalah aktiva atau kewajiban yang bersifat likuid dalam jangka waktu 3 bulan.

Pergerakan positif STM BNI Syariah dimulai sejak tahun 2010 hingga 2011, kemudian pada tahun 2011 hingga 2016 STM BNI Syariah menunjukkan pergerakkan kearah negatif dan kemudian naik kembali di tahun 2017. Hal ini terjadi karena nilai aktiva lancar ( $<3$ bulan) yang dimiliki BNI Syariah Periode 2010 - 2017 bersifat tetap, sedangkan nilai kewajiban lancar ( $<3$ bulan) BNI Syariah Periode 2010 - 2017 terus meningkat. Untuk hal ini, penulis menyimpulkan bahwa rasio STM BNI Syariah perlu ditingkatkan lagi demi menjaga likuiditas perusahaan lebih baik lagi.

Tabel 4.1 Tabulasi Rasio Keuangan

\begin{tabular}{|c|c|c|c|c|c|c|c|c|c|}
\hline \multirow{2}{*}{ Rasio } & \multicolumn{6}{|c|}{ Persentase Kinerja Keuangan BNI Syariah } & \multirow{2}{*}{ Rata-Rata } \\
\cline { 2 - 9 } & $\mathbf{2 0 1 0}$ & $\mathbf{2 0 1 1}$ & $\mathbf{2 0 1 2}$ & $\mathbf{2 0 1 3}$ & $\mathbf{2 0 1 4}$ & $\mathbf{2 0 1 5}$ & $\mathbf{2 0 1 6}$ & $\mathbf{2 0 1 7}$ & \\
\hline KPMM & 27,68 & 20,67 & 14,1 & 16,23 & 16,26 & 15,48 & 14,92 & $\begin{array}{c}20,1 \\
4\end{array}$ & 18,19 \\
\hline
\end{tabular}


102 | Galuh Gita Pratiwi, Nur S.Buchori, Mustafa Kamal : Penerapan Manajemen Mutu

dalam Meningkatkan Kinerja Keuangan BNI Syariah Periode 2010-2017

\begin{tabular}{|l|c|c|c|c|c|c|c|c|c|} 
Peringkat & $\mathbf{1}$ & $\mathbf{1}$ & $\mathbf{1}$ & $\mathbf{1}$ & $\mathbf{1}$ & $\mathbf{1}$ & $\mathbf{1}$ & $\mathbf{1}$ & $\mathbf{1}$ \\
\hline NOM & 5,07 & 8,07 & 7,31 & 9,51 & 0,47 & 0,67 & 1,01 & 0,76 & 4,11 \\
\hline Peringkat & $\mathbf{1}$ & $\mathbf{1}$ & $\mathbf{1}$ & $\mathbf{1}$ & $\mathbf{5}$ & $\mathbf{5}$ & $\mathbf{4}$ & $\mathbf{5}$ & $\mathbf{1}$ \\
\hline ROA & 0,61 & 1,29 & 1,48 & 1,37 & 1,27 & 1,43 & 1,44 & 1,31 & 1,28 \\
\hline Peringkat & $\mathbf{3}$ & $\mathbf{2}$ & $\mathbf{2}$ & $\mathbf{2}$ & $\mathbf{2}$ & $\mathbf{2}$ & $\mathbf{2}$ & $\mathbf{2}$ & $\mathbf{2}$ \\
\hline ROE & 3,65 & 6,63 & 10,18 & 11,73 & 10,83 & 11,39 & 11,94 & $\begin{array}{c}11,4 \\
2\end{array}$ & 9,72 \\
\hline & & & & & & & & & \\
\hline STM & 14,33 & 18,86 & 18,29 & 10,36 & 7,66 & 5,87 & 5,15 & 6,99 & 10,94 \\
\hline Peringkat & $\mathbf{4}$ & $\mathbf{3}$ & $\mathbf{3}$ & $\mathbf{4}$ & $\mathbf{5}$ & $\mathbf{5}$ & $\mathbf{5}$ & $\mathbf{5}$ & $\mathbf{4}$ \\
\hline
\end{tabular}

Sumber : Laporan Tahunan BNI Syariah 2010 - 2017 (Data diolah)

Jika kita amati, dari rasio-rasio yang diamati dalam penelitian ini, hampir seluruh rasio keuangan berada pada posisi yang cukup, adapun pencapaian kinerja keuangan tersebut tak luput dari penerapan manajemen mutu yang baik oleh BNI Syariah.

Secara umum, rata-rata rasio KPMM berada pada peringkat 1 , hal ini mengindindikasikan bahwa struktur permodalan yang dimiliki BNI Syariah mampu memitigasi risiko-risiko yang ada, seperti risiko kredit, risiko pasar, maupun risiko operasional. Selain itu, rasio KPMM BNI Syariah 2010 - 2017 berada diatas batas minimum modal yang ditentukan oleh OJK, hal tersebut menandakan bahwa BNI Syariah mematuhi aturan yang diberlakukan oleh regulator.

Secara umum, persentase NOM BNI Syariah berada pada peringkat 1 . Adanya hal ini menandakan bahwa BNI Syariah mampu menghasilkan keuntungan (earning) yang sangat tinggi dari kegiatan operasionalnya sebagai lembaga intermediary. Hal ini dapat memitigasi potensi kerugian yang akan terjadi juga dapat meningkatkan modal perusahaan.

Adapun rata-rata persentase ROA BNI Syariah menempati peringkat 2. Hal ini menandakan kemampuan BNI Syariah yang cakap dalam mengelola aset yang dimiliki sehingga menghasilkan keuntungan bagi perusahaan.

Pergerakan persentase ROE BNI Syariah sejak periode 2010 hingga periode 2017 penulis menilai cukup stabil. Adapun rata-rata persentase ROE sejak 2010 hingga 2017 ialah 9,72\%. Hal ini menandakan bahwa kemampuan pengembalian keuntungan atas modal yang disetor oleh pemilik modal kepada BNI Syariah dinilai cukup baik. Karena Rp 1 modal yang disetor oleh pemilik modal, maka keuntungan yang didapat ialah sebesa Rp 972.

Untuk kemampuan dalam memitigasi risiko likuiditas jangka pendek atas aktiva jangka pendek yang dimiliki BNI Syariah mengalami penurunan kinerja sejak periode 2013 hingga 2016. Angka rata-rata persentase STM BNI Syariah ialah $10,94 \%$ dan termasuk dalam peringkat 4. Hal tersebut menandakan bahwa BNI Syariah perlu meningkatkan performa dalam manajemen likuiditas. Karena rasio ini mencerminkan seberapa likuid suatu 
Jurnal Ekonomi dan Perbankan Syariah

Vol. 7. No.2, Agustus 2018: 83-106, ISSN (cet): 2355-1755 | ISSN (online): 2579-

6437

\section{| 103}

perusahaan dalam memenuhi kewajiban jangka pendeknya dengan aset jangka pendek yang dimilikinya.

Berdasarkan pergerakkan rasio-rasio keuangan di atas, penulis menyimpulkan bahwa penerapan manajemen mutu yang baik memiliki dampak dalam meningkatkan kinerja keuangan BNI Syariah, khususnya dalam kecukupan modal dan profitabilitas (ROA dan ROE).

Hasil penelitian Muttaqin dan Dharmayanti (2015) yang menyatakan bahwa kualitas kinerja memiliki pengaruh yang positif dan signifikan terhadap kinerja keuangan. Salah satu cara agar penjualan jasa satu perusahaan lebih unggul dibandingkan para pesaingnya adalah dengan memberikan pelayanan yang berkualitas dan bermutu, yang memenuhi tingkat kepentingan konsumen.

Ketika pelaksanaan manajemen mutu disuatu perusahaan/ organisasi berjalan dengan baik, maka hal tersebut akan meningkatkan kualitas atau mutu dari perusahaan sehingga menciptakan kepuasan serta kepercayan nasabah/ pelanggan yang berakhir dengan meningkatnya kinerja keuangan perusahaan.

\section{PENUTUP}

Prinsip-prinsippenerapan manajemen mutu yang diterapkan oleh BNI Syariah pusat maupun di Kantor Cabang sesuai dengan prinsip-prinsip Total Quality Management (TQM) yang dicanangkan oleh ISO pada tahun 2015, diantaranya fokus pada pelanggan, kepemimpinan, keterlibatan semua pihak, pendekatan proses, perbaikan berkelanjutan, pengambilan kepurusan berdasarkan bukti serta pengelolaan hubungan.

Adapun penerapan manajemen mutu ini memiliki dampak positif bagi rasio kecukupan modal dan rasio profitabilitas (khususnya ROA dan ROE). Hal ini dikarenakan posisi rata-rata rasio KPMM yang berada pada peringkat 1 , begitupun dengan persentase rata-rata ROA. Adapun rasio ROE BNI Syariah termasuk kategori mampu memberikan imbal hasil yang cukup tinggi bagi para pemilik modal.

Mutu adalah 'senjata' perusahaan untuk menarik minat masyarakat/ nasabah untuk menggunakan produk atau jasa perusahaan. Untuk itu, penerapan manajemen mutu yang baik akan menghasilkan produk atau layanan yang baik pula, sehingga akan menarik minat masyarakat. Ketika masyarakat puas akana produk maupun jasa perusahaan, hal itu akan meningkatkna revenue perusahaan. Dan hal ini juga dapat membantu perusahaan dalam mencapai tujuan perusahaan. 
104 | Galuh Gita Pratiwi, Nur S.Buchori, Mustafa Kamal : Penerapan Manajemen Mutu dalam Meningkatkan Kinerja Keuangan BNI Syariah Periode 2010-2017

\section{Daftar Pustaka}

Amanah, d. (2017). Jurnal Keuangan dan Perbankan Syariah. Analisis Pengaruh Total Quality Management (TQM) Terhadap Kinerja Manajerial di Bank BRI Syariah KCI Citarum Bandung, 3(2), 472-478.

Arifin, J. (2016). Jurnal At Taqadum. Penguatan Manajemen Syariah Melalui Total Quality Management Bagi Pelaku Lembaga Keuangan Syariah di Kota Semarang, 8(2), 180-209.

Azwar. (2015). Industri Perbankan Syariah Menghadapi Masyarakat Ekonomi Asean (MEA) 2015 : Peluang dan Tantangan Kontemporer. Dipetik Maret 23, 2018, dari Badan Pendidikan dan Pelatihan Keuangan Kementerian Keuangan: www.bppk.kemenkeu.go.id/

Basheer, A. A., \& dkk. (2015, November). International Journal of Business and Social Science. The Impact of Total Quality Management on Financial Performance "A Field Study In The Jordan Islamic Bank, Irbid Province - Jordan". 6(11), 65-82.

Fitri, M. (2016, Mei). Jurnal Economica. Peran Dana Pihak Ketiga Dalam Kinerja Lembaga Pembiayaan Syariah dan Faktor-Faktor yang Mempengaruhinya, 7(1), 73-95.

Haque, A., \& dkk. (2014). International Journal of Ethics in Social Sciences. Total Quality Management Practices in the Islamic Banking Industry : Comparison between Bangladesh and Malaysian Islamic Bank, 2(1).

Hery. (2015). Analisis Laporan Keuangan. Yogyakarta: CAPS (Center for Academic Publishing Service).

Imelda, H. R. (2004). Jurnal Akuntansi dan Keuangan. Implementasi Balance Scorecard pada Organisasi Publik. VI(2), 106-122.

ipqi.org. 7 Prinsip Manajemen Mutu ISO 9001:2015. Diakses pada 15 November 2017, dari www.ipqi.org/prinsip-iso-9001/.

Ismanto, K. (2009). Manajemen Syariah: Implementasi TQM Dalam Lembaga Keuangan Syariah. Yogyakarta: Pustaka Pelajar.

Kusumo, Y. A. (2008). Jurnal Ekonomi Islam. Analisis Kinerja Keuangan Bank Syariah Mandiri Periode 2002 - 2007 (dengan Pendekatan PBI No. 9/1/PBI/2007). II(1).

Lampiran SE-OJK NO. 9/24/DPbS. (2007). Diakses melalui www.bi.go.id pada 04 Juli 2018.

Laporan Tahunan BNI Syariah. (2010). Diakses melalui www.bnis.co.id pada 23 Maret 2017.

Laporan Tahunan BNI Syariah. (2011). Diakses melalui www.bnis.co.id pada 23 Maret 2017.

Laporan Tahunan BNI Syariah. (2012). Diakses melalui www.bnis.co.id pada 17 Maret 2017.

Laporan Tahunan BNI Syariah. (2013). Diakses melalui www.bnis.co.id pada 23 Maret 2017.

Laporan Tahunan BNI Syariah. (2014). Diakses melalui www.bnis.co.id pada 05 Juli 2018.

Laporan Tahunan BNI Syariah. (2015). Diakses melalui www.bnis.co.id pada 05 Juli 2018. 
Jurnal Ekonomi dan Perbankan Syariah

Vol. 7. No.2, Agustus 2018: 83-106, ISSN (cet): 2355-1755 | ISSN (online): 2579-

6437

| 105

Laporan Tahunan BNI Syariah . (2016). Diakses melalui www.bnis.co.id pada 23 Mei 2017.

Laporan Tahunan BNI Syariah. (2017). Diakses melalui www.bnis.co.id pada 26 Juni 2017.

Mawaddah, N. (2015). Jurnal Etikonomi. Faktor-Faktor yang Mempengaruhi Profitabilitas Bank Syariah. XIV(2), 241-256.

Muhammad, F. (2015). Artikel Ilmiah. Pengaruh Total Quality Management (TQM) Terhadap Kinerja Karyawan Bagian Operasional Bank " $X$ " Surabaya, 1-20.

Munizu, M. (2010, September). Jurnal Manajemen dan Kewirausahaan. Praktik Total Quality Management (TQM) dan Pengaruhnya Terhadap Kinerja Karyawan Studi pada PT Telkom Tbk. Cabang Makassar, 12(2), 185-194.

Natha, K. S. (2008). Buletin Ekonomi Studi. Total Quality Management Sebagai Perangkat Manajemen Baru Untuk Optimisasi, 13, 1-12.

Otoritas Jasa Keuangan. Sejarah Perkembangan Perbankan Syariah. Dikases melalui www.ojk.go.id pada 22 Juni 2017.

Otoritas Jasa Keuangan. Statistik Perbankan Syariah 2014. Diakses melalui www.ojk.go.id pada 22 November 2017.

Otoritas Jasa Keuangan. Statistik Perbankan Syariah 2015. Diakses melalui www.ojk.go.id pada 22 November 2017.

Otoritas Jasa Keuangan. Statistik Perbankan Syariah 2016. Diakses melalui www.ojk.go.id pada 22 November 2017.

POJK No. 8/ POJK.03/ 2014. Diakses melalui www.ojk.go.id pada 23 Juni 2018.

Sudarsono, H. (2017). Jurnal Ekonomi Islam. Analisis Pengaruh Kinerja Keuangan terhadap Profitabilitas Bank Syariah di Indonesia. VIII(II).

Surat Edaran Bank Indonesia No. 9/24/DPbS. (2007). Surat Edaran Bank Indonesia No. 9/24/DPbS Tentang Sistem Penilaian Tingkat Kesehatan Bank Umum Berdasarkan Prinsip Syariah. Diakses melalui www.bi.go.id pada 04 Juli 2018.

Tumbel, C. M., \& dkk. (2016). Jurnal Berkala Ilmiah Efisiensi. Penerapan Sistem Manajemen Mutu dalam Meningkatkan Kinerja Operasional Koperasi Simpan Pinjam (Studi pada Koperasi Glaistygil Manado). 16(03).

Veno, A., \& Syamsudin. (2016). Jurnal Bisnis dan Manajemen Islam. Analisis Tren Kinerja Keuangan Perbankan Syariah Tahun 2015 sampai dengan 2017. $I V(1)$. 
106 | Galuh Gita Pratiwi, Nur S.Buchori, Mustafa Kamal : Penerapan Manajemen Mutu dalam Meningkatkan Kinerja Keuangan BNI Syariah Periode 2010-2017 